\title{
A Sociocultural Appraisal of Yorùbá Kegites' Songs
}

\author{
George Olúsolá Ajíbádé \\ Obafemi Awolowo University \\ solajibade@yahoo.com
}

\begin{abstract}
This is a study of how the oral aesthetics of textual production by a group, the Kegites, are used in the construction of an identity rooted in a collective context that reflects a socio-political engagement with the complex social histories of the Yorùbá society and Nigeria at large. The study identifies common practices of the Kegites and themes of the texts of their songs. It shows the practice of engagement by the Kegites through which identity can be textually constructed in ways that politicize self-representation and challenge discourses grounded in the colonial and postcolonial histories of the Yorùbá people. Through the discussion of themes such as ancestral presence, the aesthetics of orature, and the political significance of group or society (egbé) among the Yorùbá, the paper seeks to showcase the presence of a characteristic of Yorùbá oral literature in which personal, cultural, economic, social and political issues become inseparable. It demonstrates how oral text reflects societal elements and performers use various societal elements to create an expression of an identity within the multiple currents and traditions by taking the rules, creativity, and artistry of self-representation and shaping them with cultural content, as well as with the rhythms and speech patterns of the Yorùbá people.
\end{abstract}

\section{Introduction}

The word 'Kegite' was formed from keg which ordinarily refers to a kind of container. Traditionally, palm wine is usually kept inside gourd called $a k$ erengbe. But as time goes on they started using keg, a form of container to keep palm wine and it is from this idea the name kegite was formed, which refers to people using keg to keep palm wine. There is paucity of literature on the activities of Kegites (members of the Palm Wine Club student association) 
in tertiary institutions in Nigeria. There is the work of Odejide et al. (1987), who carried out a cross-sectional study of drug use involving 2,079 senior secondary-school students in two major cities of Nigeria (Ibadan and Abeokuta). Rates of alcohol use were 56\% for Ibadan and 51.5\% for Abeokuta. They concluded in their work that males use alcohol more than the females in Ibadan and Abeokuta. They added that alcohol use was more common among younger students in the lower-school classes and among those from higher and middle socioeconomic backgrounds. Alcohol drinkers were also found to be more involved in accidents and the use of other psychoactive drugs than non-drinkers. Odejide (1989) in his inaugural lecture proved that the Nigerian nation is at great risk due to high prevalence of alcoholic drink consumption among the youth. It has also been observed that both sexes, both in the underage groups as well as adults, use alcohol essentially for pleasure and for overcoming psychological and physical problems (Odejide and Odejide 1999).

Similarly, Ohaeri et al. (1996) examined how the ideals of the Kegites' club are reflected in the general and drinking behavior of members, highlighting the elements of these ideals and behavior that can be of use in preventive drug education among youths in Nigerian institutions of higher learning. They focused mainly on the university of Ibadan (southern Nigeria) and university of Jos (northern Nigeria). They concluded that when compared with previous studies of Nigerian general population samples, it appears that, while Kegites drink much more alcohol than other students, their rate of use of other psychoactive substances is similar to that of the general population. On the university campuses, for instance, there have long been student drinking associations such as the known as the Kegites alongside those organized as confraternities (Pratten 2009).

Afolabi (2011) examined the sociolinguistic aspect of the language and communication patterns of the Palm Wine Drinkers Club (Kegites) with special attention paid to aspects of the morphology, semantics, lexis, and syntax of the club's language. He concluded that the evolution of the language within the interethnic social club could be seen as a typical example of sociolinguistics and an applied linguistics paradigm.

\section{Research Methodology}

This study relies extensively on data gathered from in-depth interviews conducted with members of the Palm Wine Drinkers Club at the Obafemi Awolowo University, Ile-Ife, University of Ibadan; Adekunle Ajasin University, Akungba-Akoko; Ibadan Polytechnic; the Federal Polytechnic, Esa-Oke; and Adeyemi College of Education, Ondo. During the fieldwork, which took place between 2009 and 2015, there was participant-observation of the researcher 
at their shrines (meeting places). Many of their songs were recorded on audio and video tapes and were transcribed. In addition to oral data, the research benefitted greatly from sources from the Internet. The collected data were analyzed, using sociological and hermeneutic approaches.

\section{The Kegites: Origin and History in Nigeria}

The Kegites Club or the Palm Wine Drinkers Club is one of the most popular socio-cultural groups in Nigerian tertiary institutions. Reportedly, the club's membership is boasts of about 110,000 members both within Nigeria and other parts of Africa, Europe, and the United States of America. According to Afolabi, it was founded in 1962 at the University of Ife when it was located where Ibadan Polytechnic is currently located. Since then, it has spread to most universities and colleges across Nigeria. The branch at the University of Ibadan was the second to be established, in 1972. The objectives of the club are to promote African culture and foster friendship among youths of institutions of higher learning. Official engagements are characterized by joyful exuberant singing, drumming, and dancing, in which the only alcoholic drink allowed is palm wine, with strict rules to prevent intoxication (Ohaeri et al. 1996).

At the inception, it was their informal pastime to converge and imbibe palm wine every evening after a hard day's work, when the ideal of forming a sociocultural club dawned on them. All this happened while they were still at the "mother shrine" (the current Ibadan Polytechnic site). Afterward, the ideal blossomed and officers were appointed, and the president was to be called a chief as is the tradition in the African setting. Olusegun Adeshina, a professor, became the first president of the club (Afolabi 2001). Though the club is mainly and was initially only for students, its membership was later opened to anybody who wanted to join, as long as he or she could keep to the club's rules and regulations. The Obafemi Awolowo University where it started (while they were still at the University of Ibadan before it moved to the current permanent site in Ile-Ife) has remained its world headquarters. The club that started in 1962 has grown and extended beyond Nigerian shores as members are now found in the United Kingdom and the USA, Canada and other African nations. There are diverse opinions about this club, ranging from the negative to the positive. Many students opine that the Kegites Club is a semi-cult group, while others, who are either directly or indirectly involved, see the club as an avenue for fun and relaxation from academic stress and rigor. According to the members who were interviewed, "any member found guilty of being involved in cultism or any other vice will be immediately expelled in what is tagged 'de-kegation,' an experience that Kegites consider an abomination". 
Although the days of their meeting vary from one Ilya (shrine) to another, the common day of meeting in most of the ilyas is Thursday. At Adekunle Ajasin University, Akungba-Akoko (AAUA), and Obafemi Awolowo University, IleIfe, Thursdays are for the weekly "fellowship" or "tapping." The group adopts terminologies associated with Christian groups on campuses primarily to imitate them. Their meetings usually begin at 4:30 p.m., to align with the end of the workday for most members.

The shrine of the Kegites Club at the Obafemi Awolowo University, Ile-Ife, being the world headquarters is not called an ilya. Instead, it is called "Mother Shrine"; that of the University of Abuja is called "National Shrine" because it is located at the national's capital. Each Ilya has its appellation. For example, the branch at the Polytechnic, Iree (Osun State) is called Ilya Duomio. Others are Ilya Kakanfo (College of Education, Oyo), Ilya Ondo (Adeyemi College of Education, Ondo), and Ilya DuAfonja (University of Ilorin). It must be pointed out here that there is a contention in regard to the issue of national headquarters of the Kegites Club. The branch at the University of Ibadan claims that Kegites Club started at their university; hence, they regard their branch as the mother shrine and the national headquarters for other shrines.

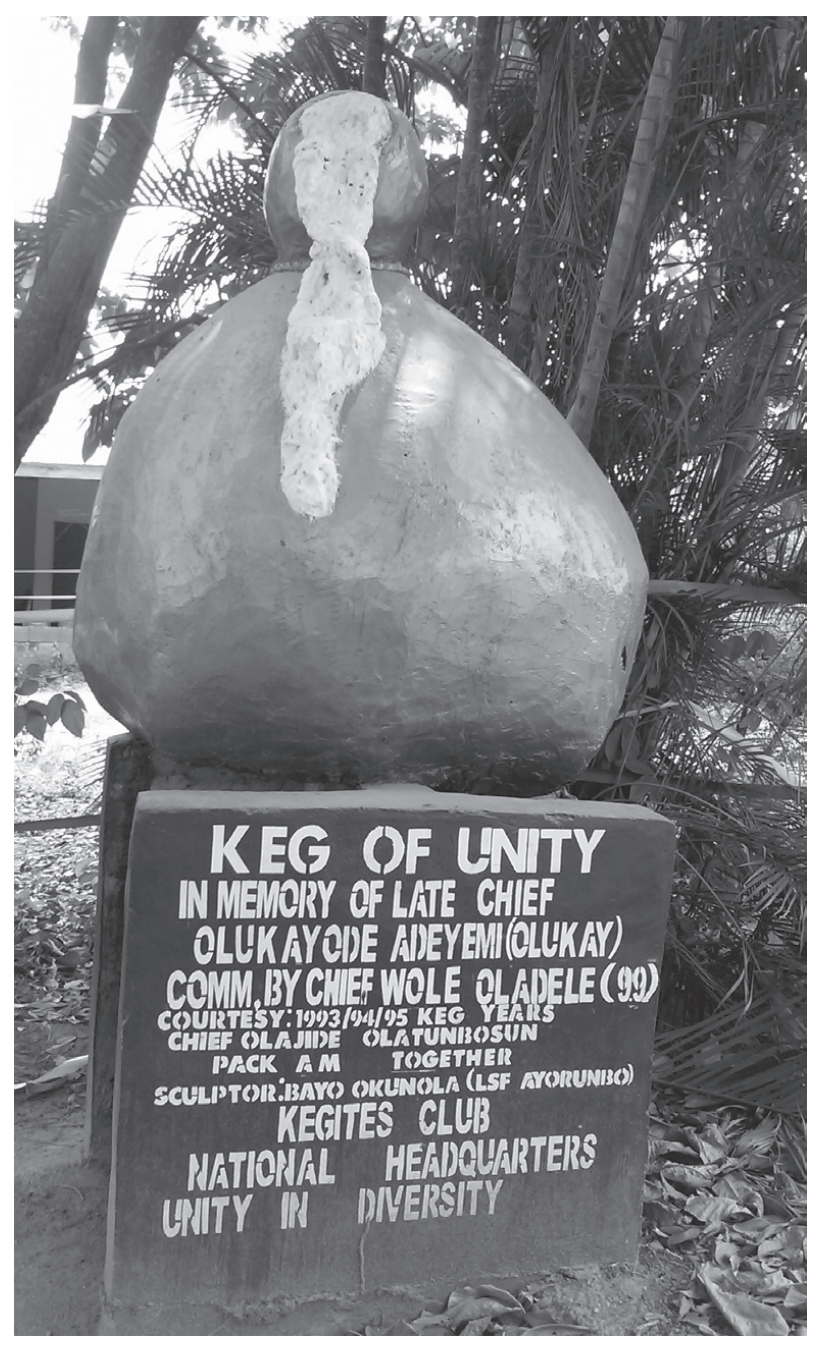




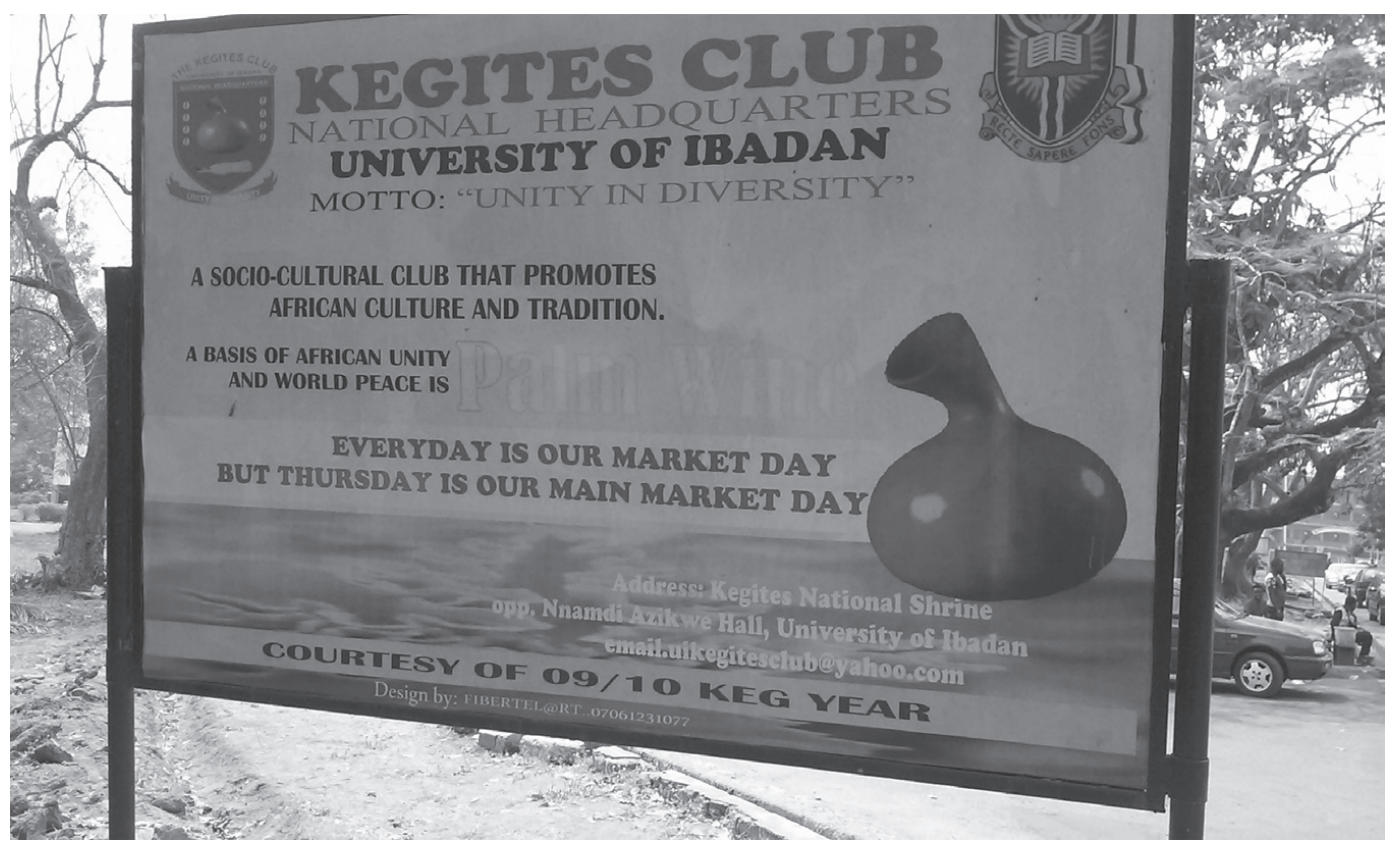

This idea has been sustained in this university because the University of Ibadan was the first university to be founded in Nigeria.

The Kegites' fellowship integrates drinking, dancing, and general entertainment. Their activity is not limited to the campus; they also perform on special occasions such as at matriculation and convocation ceremonies or whenever any member invites them to grace a particular celebration. As a rule, Kegites use a calabash (ahá) to drink palm wine. Drinking palm wine from a calabash is seen as one of the ways to preserve African (specifically Yorùbá) culture, as well as to promote the unity of the African continent (Ojerinde 2010).

The Kegites Club maintains a hierarchical structure. In naming the various categories, the club freely draws names from the immediate environment. The executive members are called G-Lords. Below is the hierarchy in the organization. 


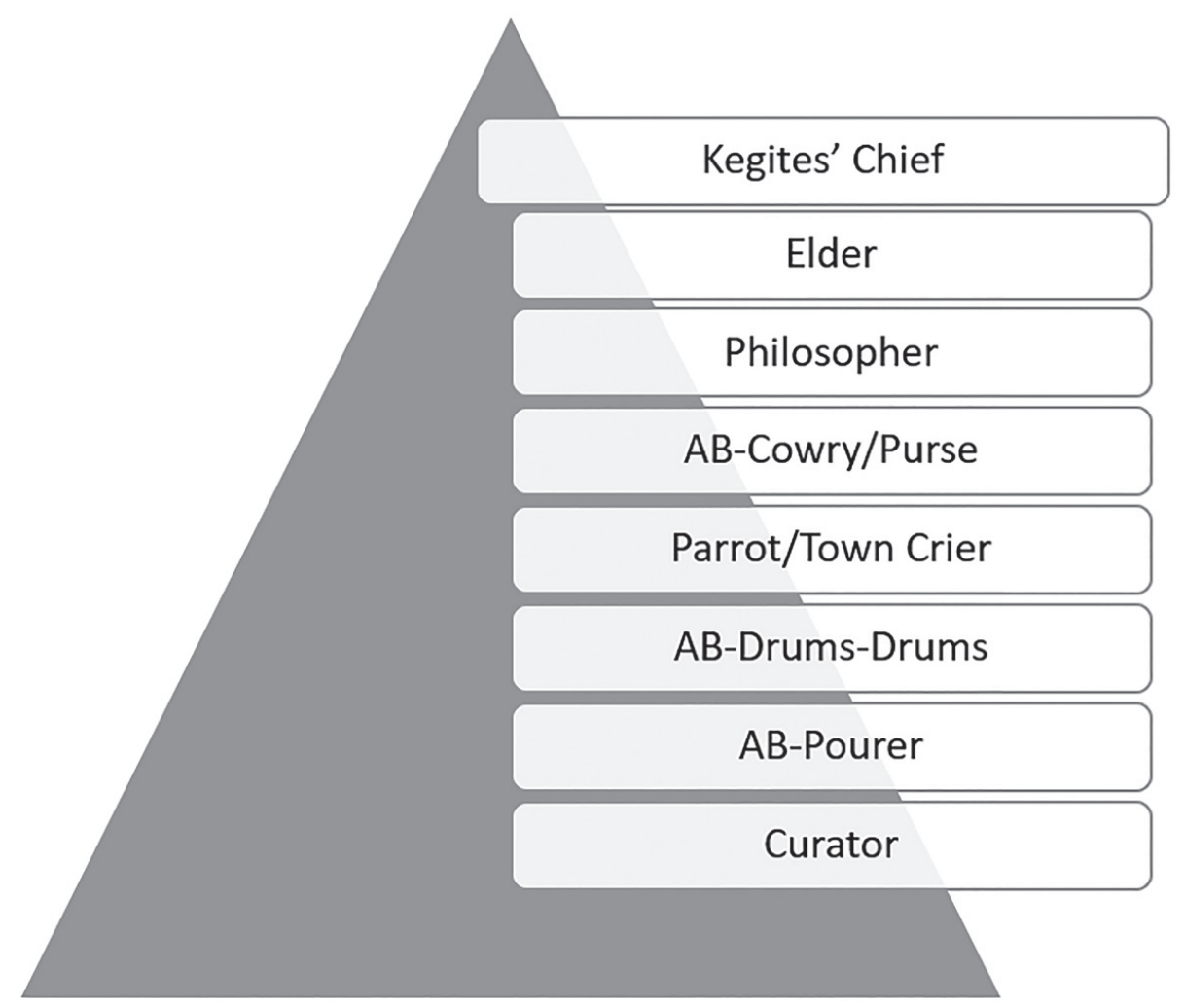

The Chief (aka G-Lord) is the overall leader of the club at every Ilya. Next to the Chief is the Elder who is the deputy to the Chief. The Philosopher is next to the Elder. The Philosopher is the custodian of history and cultural matters in the club. AB-Cowry is next to the Philosopher in rank. He/she is in charge of the purse of the club (Ilya). The Parrot, also called the Town Crier, is the next in rank to the $\mathrm{AB}$-Cowry. He/she is the public relations officer of the club. Next to the Parrot is the officer called AB-Drums. He is the head of all drummers and also in charge of drumming in all performances of the club. The Pourer is next in rank to the AB-Drums. The Pourer is in charge of serving of palm wine either at the shrine or at the outings of the club. The Curator is the last in rank. He/she is in charge of all cultural matters of the club.

\section{Emu in the Yorùbá Traditional Society}

$E m u$, sap, typically collected from the cut flower of the palm tree, is extracted and collected by a tapper (adẹmu). A container (agbè or akèrèngbè) is fastened to the flower stump to collect the sap. The white liquid that initially collects tends to be very sweet and non-alcoholic before it is fermented. An alternative method is the felling of the entire tree (àgbá ibúlè). Where this is practiced, a fire is sometimes lit at the cut end to facilitate the collection of 
sap. Palm sap begins fermenting immediately after collection. The wine may be allowed to ferment for a longer period, say, up to a day, to yield a stronger, more sour and acidic taste, which some people prefer. This is called isà. Palm wine may be distilled to produce stronger drink called ogógóró. Due to abuse of this brand of alcoholic drink that is made from palm wine various appellations have been given to it to lampoon people who indulge in it to excess. These include fònàgáú (cross the road carelessly as someone with absent mind), sẹ́pẹ (something that can break anyhow), and pẹlẹbe (something flatjust describing one type of container which alcohol is served with) among others.

In the traditional Yorùbá society, palm wine is not usually associated with anything negative. Just like the philosophy of the people on other matters, palm wine is viewed from two angles of good and of evil. Palm wine is used as traditional medicine to cure diseases such as gonorrhea, syphilis, and especially fever. This perception or practice is encapsulated in the aphorism, "ẹmu loogùn ibà" (palm wine is the medicine that cures fever). Palm wine occupies an important place in the ritual space, especially during traditional festivals and ceremonies. Palm wine plays an important role in many ceremonies among the Yorùbá peoples. Guests at weddings, birth celebrations, and funeral wakes are served generous quantities. Palm wine is often infused with medicinal herbs to remedy a wide variety of physical complaints. As a token of respect to deceased ancestors, many drinking sessions begin with a small amount of palm wine spilled on the ground. Palm wine is enjoyed by men and women, although women are not as likely to drink it in public places as men. It must be pointed out that the twin sister of palm wine is called ogùrọ. It is made from raffia palm trees called $i k o$. The methods of tapping the two are similar.

Palm wine is a widely acceptable beverage among the Yorùbá and it is received with great enthusiasm whenever offered to somebody, either a visitor or during any celebration or ceremony. This results in the saying, a ki i rẹ́mu ká rojú (no one squeezes his face whenever offered palm wine). Among the Yorùbá, someone who is fond of or addicted to palm wine is usually praised thus: a-rẹ́mu-kinńkin-rojú (the one who squeezes his face when given a small quantity of palm wine). The above statement is usually uttered to sarcastically lampoon an individual who engages in excessive consumption of alcohol. In drinking palm wine, the Yorùbá detest excessiveness, and they abuse the drunkard as alámutọsílè (the one who pisses on the floor). When someone drinks palm wine excessively, the Yorùbá people believe that such a person has been afflicted by occult powers with a gourd inside his stomach, which is making him to crave palm wine at all times. Emu also occupies a central place and space in the worship of the traditional deities of the Yorùbá people. 
For example, emu is noted to be the favorite of Ògún, the god of iron, while it is taboo for the worshippers of Obatala, the arch divinity. ${ }^{1}$ During the worship of Ògún, the sacrifice is incomplete without a libation of palm wine at the shrine. This shows the importance of palm wine to this deity. Not only this, because palm wine is the favorite drink of Ògún, the adherents cannot but drink palm wine during Ògún festivals. In fact, the appellation of one of my respondents is Arígbáńlá-mẹmu-Ògún (The-one-who-uses-big-calabashto-drink-Ògún's-palm-wine). This portends that he takes joy and pride in drinking palm wine in order to be seen as faithful to Ògún, the god of iron. Whenever there is an outbreak of smallpox, drinking of palm wine is encouraged. The adults are told and encouraged to drink palm wine while the children are rubbed with palm wine in order to appease Șànpọ̀nná, the god of smallpox/chickenpox. ${ }^{2}$ Those we interviewed showed their strong belief in the efficacy of palm wine in curing chickenpox, even in the contemporary society.

\section{The Kegites, Identity Creation and Christianity}

The Kegites sing various types of songs. A member of the group even asserted that "the Kegites sing various songs because we see ourselves as entertainers, social crusaders, preachers, historians, and apostles. We sing according to situations." The Kegites mix oral generic features of Yorùbá traditional songs, Christian songs, and other forms of songs in their composition, which practice could be seen as intertextual, echoing the language of Bahktin. With copious references to a wide array of Christian songs and less of classical and traditional oral poetry, the Kegites have been able to use their creative ability to compose a distinct oral genre that is performed from time to time during their meetings and at other outings of their club. Texts of the Kegites' genres are not careless utterances, as they are cryptic with meanings and their performances could also be seen as dramatic:

Ma fi rẹ̀lè gbé tọ́ńbilà

Ma fi pẹlé gbáá ẹmu

1 According to the Yorùbá myth of creation, Obàtálá was saddled with the responsibility of creating the earth and he was unable to complete the job because he drank palm wine and became intoxicated. It was Oduduwa, the acclaimed progenitor of the Yorùbá, who eventually completed the job. In another myth, it is said that before Obàtálá was sent to bring life to the earth he was responsible for molding human beings before the supreme Deity would breathe life into the molded structures. But because Ọbàtála would at times become intoxicated, he molded some human beings with deformity.

2 Șànpọ̀nná is known with other names such as Olóde, Bàbáàgbà, NànáBùkú. The belief behind these names is that Șànpọnná is a dreadful deity that should not be called without reverence. 
Elẹmu mímọ́, Elẹ́mu mímọ

Elẹmu mímọ́, Elẹmu funfun

Elẹmu ọpe

Elẹmu ògùrò̀

Ó láhá funfun

Ó lágbè funfun

Olùpèsè ẹmu la ó máa pè é

Ó fagbè sọ́wọ́ ọmo rẹ òsi

Kọộbù sọ́wọ ọmọ rẹọtún

I will reverently carry a glass cup

I will gently carry calabash of palm wine

The one who has clean palm wine

The one who has clean and white palm wine

The one who has wine from palm tree

The one who has wine from raffia tree

He has a clean/white drinking calabash

He has a clean/white palm wine gourd

He shall be called palm wine provider

He puts gourd in the left hand of his child

He puts a cup in the right hand of his child

The first four lines of the above song reveal the Yorùbá belief that God is the provider of all things in life, from which palm wine is not exempted. This idea is reinforced in the seventh line, "He shall be called palm wine provider." The last two lines reveal the Kegites' belief that God, the one who creates all things in Yorùbá belief, is the one who created palm trees from where palm wine is tapped. Not only this, gourd in the left hand and cup in the right hand is replete with meaning. One, it means that God has put the gourd in the left hand and cup in the right hand, and is describing God as the one who approves the drinking of palm wine. In the traditional Yorùbá setting and even in the contemporary society, the gourd (for storage) and the calabash (for serving) are very important at the drinking joints. The above song was modeled on the lyric of a song by Bisi King, a notable Yorùbá Christian singer in southwestern Nigeria.

Another song formed from a Christian worship song is as follows:

Elẹmu ni yóó máa mọ̀wé e rẹ

Eni tí kò mú ún kó le mọ̀wé

Elẹmu ni yóó máa mọ̀wé e rẹ lọ 
It is the drinker that will succeed in his studies (repeat)

The person who doesn't drink cannot do well in his studies

It is the drinker that will succeed in his studies (repeat)

According to one of the Kegites, being a member of the society does not mean that such a person should not do well in his or her studies. This idea is encapsulated in the song to arouse other students' interest in the group.

\section{The Kegites and Sociopolitical Issues}

Humor can develop and sharpen cognitive tools that help people construct meaning and sense. In oral cultures, thinking involves the complex logic of metaphor more than it follows the systematic logic of rational inquiry. Humor is replete with metaphor and other literary tropes. Hence, language that is rich in metaphor can stimulate creativity. It is understandable that words, either spoken or written, could be used to generate images in the mind of the audience. To this end, imaginative thinking in humor and satire creates a picture in the mind and this image-generation is a cognitive tool (Mawter 2007, 11). The song below is a good example in a case where the Kegites sing humorously to depict sexual imagery in the mind of the audience.

İyàwó ń lọta

İlẹkè̀ ń șasọ

İlẹkẹ má ṣasọ mọ́ o

Jẹ kí iyàwó lọta

Olófóófó yẹra

A fẹ sọ̀rọ awo

The bride is grinding pepper (on the mill)

The beads are grumbling

Beads, stop grumbling

Let the bride finish grind the pepper

You traitor move away (from us)

We want to discuss a secret

To a greater extent than words and images, music requires a shared cultural background. The song above has some cultural underpinnings. Among the Yorùbá of southwestern Nigeria, beads are common with women, especially the newly married. To them, beads are not only a symbol of beauty but also an instrument of endearment, and have communicative competence. The 
shaking (called grumbling) of the bead arouses the sexual appetite of the groom and this leads to the "discussion of a secret," meaning having sexual intercourse. The whole song is a message that sexual intercourse should take place after the woman has finished her domestic chores. The Kegites borrow this song from the pool of Yorùbá women folksongs. In other words, the song was developed from the Yorùbá women's folksongs and its understanding requires the knowledge of its historical background. This is in line with the observation of Hepburn $(1983,496)$ that:

How a competent reader approaches a work of literature, his attitude and expectations, depend importantly upon the genre he sees it as exemplifying. A work that rebels against genre-conventions equally relies on the reader's recognition of the conventions being rejected. Aesthetically relevant features of a work may stand out only if its reader has a background awareness of the historical development of the genre, or of the style, that the work is transforming in its distinctive way and perhaps without direct allusions within the text itself. The work demands to be seen against the foil of the whole tradition from which it stems, and which it modifies by its very existence. (cited in Swales 1990, 37)

The last two lines of the above song are from another song, the primary context of which the Kegites violated in order to give additional information to what is expected to happen when the bride finishes grinding the pepper. Communicative processes following more or less fixed patterns are called genres. Genre knowledge is also employed when the speakers violate expected patterns in such a way that further information is located precisely in the violation.

One can argue that the major crisis confronting an adolescent is associated with establishing his or her identity and avoiding identity diffusion, and that the interpersonal dimension that emerges during this period has to do with a sense of ego identity. Because the adolescent's body is changing rapidly, the developing self-image coincides with the identity crisis. As adolescents break away from the close guidance of their parents, they seek support elsewhere, usually with a peer group. In the developmental stage, an adolescent may view smoking, or the use of alcohol and other drugs, as a way of expressing a growing sense of independence (Bandura and Walters 1963 and Bandura 1977).

One of the songs the Kegites perform at the naming ceremony that focuses on their identity as drinkers and that they take pride in it is as follows:

I love palm wine, I no go lie

$\mathrm{Na}$ inside the shrine I go marry my wife 
I no go lie

My father is a tapper, I no go lie

My mother is a seller, I no go lie

$\mathrm{Me}$, I am a consumer, I no go lie

People communicate knowledge of one another in various ways and thereby affirm their identity as part of the in-group. Friendly irony allows the in-group to deal playfully with social differences, which thereby receive acceptance. The participants leave the domain of official politics and playfully create a high level of intimacy (Kotthoff 1996). From our observation, the Kegites prove that there is a relationship between an individual's need for sensory stimulation and a host of other acts such as the use of palm wine (alcohol) and singing of songs. All individuals seek varied experiences and stimulation but have different optimal levels of arousal and different means of sensory stimulation. Some use alcohol or other drugs, eat, smoke cigarettes, engage in sexual activity, or attend religious meetings and programs on the campus as sources of sensory stimulation. The primary functions of sensation-seeking are to provide new experiences, reduce boredom, facilitate dis-inhibition, and offer adventure.

Characteristic of the Kegites' genre is the emergent production of a shared fantasy, often with several conversational participants making short contributions which create coherent scenes through the incremental structuring and augmentation of fun and funny words and jokes. The genre shows how interlocutors put each other on inferential tracks and how these tracks can be processed, drawing on the relevant contextual knowledge, so that the humor can be immediately "topped" (to use an ethnographical term). It shows how several persons closely oriented to each other select formulations which produce a coherent fiction, until the created scene is conversationally phased out again.

In joint fantasizing, condensed information is quickly added on to produce the most absurd fictive scene; the short turns iconize the tempo of building up the structure. The particular artistry of participation in the formation of such fantasies consists in doing this rapidly.

We viewed genres from a performance perspective and witnessed how an actual co-construction of ongoing discourse indexes social relationships, moral stances, cultural intricacies, and a certain context. The Kegites in many instances use their songs to show that they are promoters of ethics in the society. Part of this is discernible in a song against extramarital practices, as seen below.

Rọra șe o İyàwó ilé rọra

Aláṣejù pẹrrẹ ní tẹ 
Nígbà tó o bá gbé jombo

Ti gbogbo ilé ní ó dà

Rọra șe o İyàwó ilé rọra

Be careful, housewife, be careful

The one who outdoes things usually run into troubles

When you contact problem

It becomes the problem of the whole family

Be careful, housewife, be careful

This song was used to lampoon wayward married women and prostitutes. The sense of these lyrics is to bemoan the misfortunes associated with harlotry, which of course has to be set against an imagined normalcy, a projected future of marriage. In the end, extramarital affairs will have consequential negative effects not only on the victim but on the entire family. Another song that they have used to satirize the Nigerian regimes right from the time of independence is:

Ewo lewo o ewo lewo?

Omo elemu ewo lewo?

Oyinbo lo tan o

Balewa de

Balewa lo tan o

Ironsi de

Ironsi lo tan o

Gowon de

Gowon lo tan o

Muhammed de

Muhammed lo tan o

Olusegun de

Which one can you say is better?

Children of palm wine (Kegites) which do you say is better?

The Europeans departed

Balewa came

Balewa departed

Ironsi came

Ironsi departed

Gowon came

Gowon departed

Muhammad came 
Muhammad departed

Olusegun came

The Kegites use the above song to show their knowledge of Nigeria's sociopolitical history by giving a chronology of Nigeria's past leaders. They use their performance license and space to relate their knowledge and reactions to the sociopolitical happenings within Nigerian society. The following are the past leaders of Nigeria:

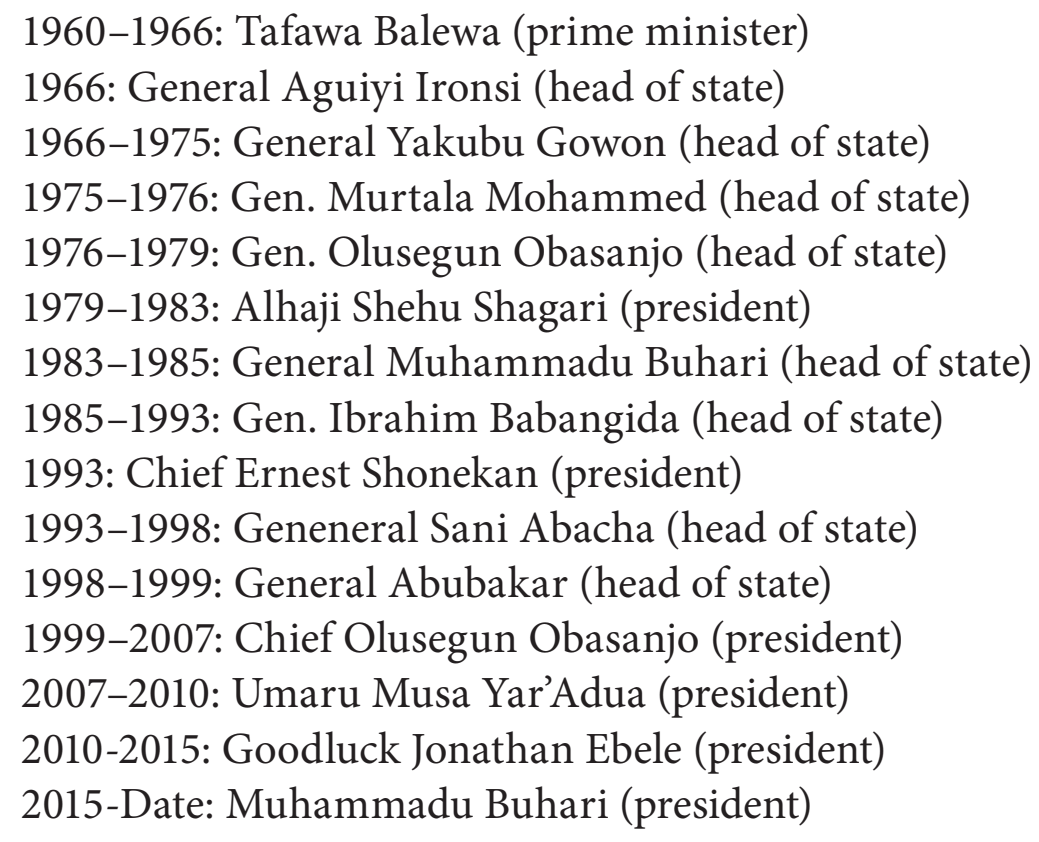

Although the Kegites, through the above song, list the past leaders of the country, the thrust of the song is the expression of displeasure with various regimes, especially the military, in Nigeria. They posit that none of these regimes can be praised, for they failed to contribute meaningfully to the development and progress of the state. This they convey in their song using rhetorical questions to show hopelessness and disappointment in these various regimes. They use their songs to express the view of the populace concerning various Nigerian regimes. Their submission is that that none of them has really manifested loyalty to the state, as evident in the suffering of the masses due to poor governance.

\section{Conclusion}

The literature on Kegite subcultures focuses predominantly on psychological and sociological perspectives. The emphasis is on how they use oral discourse (songs) as a culture of boundary-making in membership identity, signification, group solidarity, and cultural production. The palm-wine clubs in Nigerian tertiary institutions have long provided a valuable lens on the 
dynamics of social change on the continent. This includes but is not limited to the cultural values attached to the cultural heritage that has suffered from colonialism and globalization. Their musical performance is also a way of preserving traditional performance tradition and aesthetics. This plurality of aesthetic styles of the Kegites cannot be underestimated as each scene captures a register of practice and representation. Kegites perform within different visual registers, each of which is dynamic and at the same time a way of revealing the group as a musical troupe, as a cultural group, as critics of the Nigerian social fabric, and as modern performers. The Kegites' musical performances reveal theoretical metaphors of cultural syncretism, creolization, and hybridism, which might otherwise provide suitable models of cultural appropriation as culture and aesthetics constitute an open-ended construction of merging the existing infrastructures with new ones.

\section{References}

Afolabi, Olakunle Ayodeji. "A Sociolinguistics Study of the Kegites (Palm Wine Drinkers Club) Language.” Bukisa.com, Feb. 28, 2011. http:// www.bukisa.com/articles/461138_a-sociolinguistics-study-of-the-kegites-palm-wine-drinkers-club-language (accessed Sep. 9, 2016).

Bandura, A., and R. H. Walters. Social Learning and Personality Development. New York: Holt, Rinehart and Winston, 1963.

Bandura, A. Social Learning Theory. Englewood Cliffs, New Jersey: Prentice-Hall Inc., 1977.

Kotthoff, Helga. "Impoliteness and Conversational Joking: On Relational Politics". Folia Linguistica 30, nos. 3-4 (1996): 299-327.

Mawter, Jeni. All You Need to Teach: Critical Thinking, Humour and Text Ages 8-10, Australia: Macmillan Teacher Resources, 2007.

Odejide, A. Olabisi, J. U. Ohaeri, Moruf L. Adelekan, and B. A. Ikuesan. "Drinking Behaviour and Social Change among Youths in Nigeria: A Study of Two Cities." Drug and Alcohol Dependence 20, no. 3 (1987): 227-233.

Ohaeri, Jude U., Samuel O. Oduyela, Olabisi A. Odejide, T. M. Dipe, Princewill U. Ikwuagwu, and Andrew Zamani. "The History and Drinking Behaviour of the Nigerian Students' Palm Wine Drinkers Club.” Drugs: Education, Prevention and Policy 3, no. 2 (1996): 171-183. Retrieved from http://www.informaworld.com/ (12 April 2011).

Odejide, A. O. "A Nation at Risk: Alcohol and Substance Abuse among Nigerian Youths." Inaugural Lecture, University of Ibadan, 1989.

Odejide, A. O., and B. Odejide. "Harnessing Pleasure for Population" In Alcohol and Pleasure: A Health Perspective, edited by S. Peele and M. Grant, 341-356. Washington: International Centre for Alcoholic Policy, 1999. 
Ojerinde, Dayo. "For the Love of Palmwine and Gyration." The Nation, 24 June, 2010.

Olodo, Oyeyemi. "Nigerians Need a Kegite Leader as the Next Nigerian President, Kegites Members Declared." Online Nigeria, 26 September 2006. http://www.onlinenigeria.com/columnists/ad.asp?blurb=345 (accessed 12 September 2016).

Pratten, David. "The Agaba Boys: Gang Culture and Radical Insecurity in Nigeria." Paper presented at the International Gangs Workshop. Geneva, May 2009.

Swales, John M. Genre Analysis: English in Academic and Research Settings. Cambridge: Cambridge University Press, 1990. 